\title{
Determinants of Purchasing and Loyalty of European Guests Choosing Green Hotel
}

\author{
Nining Yuniati \\ Sekolah Tinggi Pariwisata Ambarrukmo (STIPRAM) Yogyakarta \\ Corresponding Author: niningyuniati@gmail.com
}

\section{ARTICLE INFO}

Received

20 June 2020

Accepted

31 August 2020

Available online

30 September 2020

\begin{abstract}
It is very important to pay attention to what is considered in consumer purchasing decisions. European visitors are guests who are quite dominant as green hotel users in Yogyakarta. This study seeks to examine a model of purchasing behavior and loyalty of visitors from Europe. By examining a sample of 215 hotel guests, it was found that from the five variables that were indicated to influence the decision to choose green hotel i.e. experience, environmental concern, image, price, and reference group, it turns out that price does not have a significant effect. This means that segments that have a high environmental concern tend to prioritize factors beyond price. European visitors can then be referred to as green consumers who have characteristics including hassle-free segments, easy to manage, and less complained. This study also examines the relationship model between Purchasing, Satisfaction, and Loyalty on green consumers, where satisfaction is an important element in fostering customer loyalty.
\end{abstract}

Keywords: green consumers, green hotel, purchasing behavior

\section{INTRODUCTION}

In recent years, a number of business actors in the hospitality sector have stated that there is an increasing trend of interest from consumers, especially foreign guests in some tourist destination in Indonesia, to use environmentally friendly hotel concepts that are often called green hotels. The green hotel concept according to the Green Hotel Association is an environmentally friendly hotel that is http://ojs.unud.ac.id/index.php/eot managed with great attention to the use of resources and energy, efforts to reduce waste and other forms of resource efficiency in order to maintain environmental sustainability.

The tendency of an increase in green hotel enthusiasts actually has also occurred in a number of other countries where hotels with green services are more in demand than conventional hotels (Theotokis and Manganari 2015). A survey e-ISSN: 2407-392X. p-ISSN: 2541-0857 
of 30,000 travelers also noted that based on uploaded testimonials on the TripAdvisor tourist site, it was mentioned that around $79 \%$ of travelers liked green hotels ( $\mathrm{Yu}, \mathrm{Li}$, and Jai 2017).

An interesting focus related to changes in the trend of tourist behavior in choosing a green hotel is a discussion of the determinants that influence their decisions in choosing a green hotel. According to Joshi and Rahman (2015) the decision to buy environmentally friendly products is part of green purchasing, which is defined as purchasing that cares for the environment and is done by consumers who have an awareness of environmental protection and care about eco label products.

Some studies have concluded that there are various factors that influence green purchasing: 1) price (Johri and Sahasakmontri 2016) a tradeoff between nominal issued with the value obtained, 2) brand image (Berezan, Millar, and Raab 2014) as a guarantee of the reputation of services to be provided, 3 ) reference groups (family, relatives, travel agents) (Anvar and Venter 2014) 4) environmental concern (Mun 2014) is an individual awareness of the environmental impact arising from its decision, and 5) green experience ( $\mathrm{Yu}, \mathrm{Li}$, and Jai 2017) is an aspect of the guest experience when staying in a green hotel before.

http://ojs.unud.ac.id/index.php/eot
According to $\mathrm{Yu}$ et.al (2017) research on the determinants that affect green purchases still leaves debates and inconclusive. On the other hand, explorative research on green purchasing and its effect on customer satisfaction and loyalty to green hotels have never been done. Research ever conducted by Bastic and Gojcic (2012), regarding the satisfaction of green hotel, the formulation of the dimensions of customer satisfaction measurement has not been found. Likewise, the research on the relationship between the level of satisfaction and loyalty (Chang \& Fong, 2010). The relationship between green purchasing, customer satisfaction, and loyalty is a rare theoretical construct and on this basis, it will be an important discussion in this research by finding the interrelationships between these three variables.

Understanding the terminology of satisfaction in the context of research is about how to find the dimensions of satisfaction of services that are appropriate for a green hotel. According to Bastic and Gojcic (2012) green service instruments that can be distinguished from conventional hotels at least contain: 1) attributes 2) energy saving facilities, 3) attitude and service of hotel staff, and 4) bio food provided in the food menu. Then, the notion of loyalty in this context refers to the opinion of Chang and Fong (2010) is the 
willingness to re-visit, or the desire to recommend to other parties.

Referring to the statement above, it is interesting to see what determinants influence green purchasing, is there any effect on green customer satisfaction and finally how satisfaction can have an impact on green customer loyalty. The study of tourists from Europe is considered as one of the right ways to find out the relationship between variables as a construct. European visitors are considered to be able to represent the population of foreign tourists who use green hotels, because most green hotel guests in Indonesia are European visitors.

\section{RESEARCH METHOD AND HYPOTHESES DEVELOPMENT}

Based on its objectives, this study included the type of hypothesis testing. Research carried out for approximately 2 months (November - December 2019). The sampling population is European visitors who stay at green hotels in Yogyakarta. Green hotel means a city hotel hotel that practiced effieciency in operational and some are has officially won the green award. Yogyakarta was chosen as a research area because it is one of the leading tourist destinations in Indonesia.
Currently the population of foreign tourists in Yogyakarta reaches 533,000 (based on data guests who staying at the Hotel), of which $40 \%$ European, $37 \%$ Asian, and the rest in smaller populations are Australiaan, US, and Middle East. The European especially are from Netherlands, Germany, France, and UK. The European market segment has sufficiently dominated the foreign visitors segment in Yogyakarta over the past 10 years.

The sampling technique used is non-probability sampling by considering the time of the study, the sample taken was only 215 respondents from Europe who had stayed more than 1 day at the hotel as an incidental sample. The instrument used was a questionnaire with closed questions. The survey conducted for approximately 6 weeks in was in the peak season for foreign tourists.

This study involves a number of variables and each variable has a number of indicators that are measured using a Likert scale with ranges 1 - $5(1=$ Strongly Disagree; 2 = Disagree; 3 = Neutral; 4 = Agree; 5 = Strongly Agree). There are five independent variables (Green Experience, Enviromental Concern, Image, Price, Reference Group) and three dependent variable (Green Purchasing, Green Customer Satisfaction, Green Customer Loyalty) as illustrated at Figure 1 and 
Construct measurement and indices are provided in Table 1.

A number of variables and indicators were developed in this study. Referring to the previous research model which has been tested by examining the role of satisfaction in building loyalty (Yuniati et al. 2020), in this study more specifically described antisedent variables and taking the special case of European visitors.

The method of analysis is Partial Least Square (PLS) a second generation multi-variant data analysis tool, needs less stringent requirements than the Covariance-based Structural Equation Model (SEM) (Hair et al. 2017).The software used is SmartPls3.

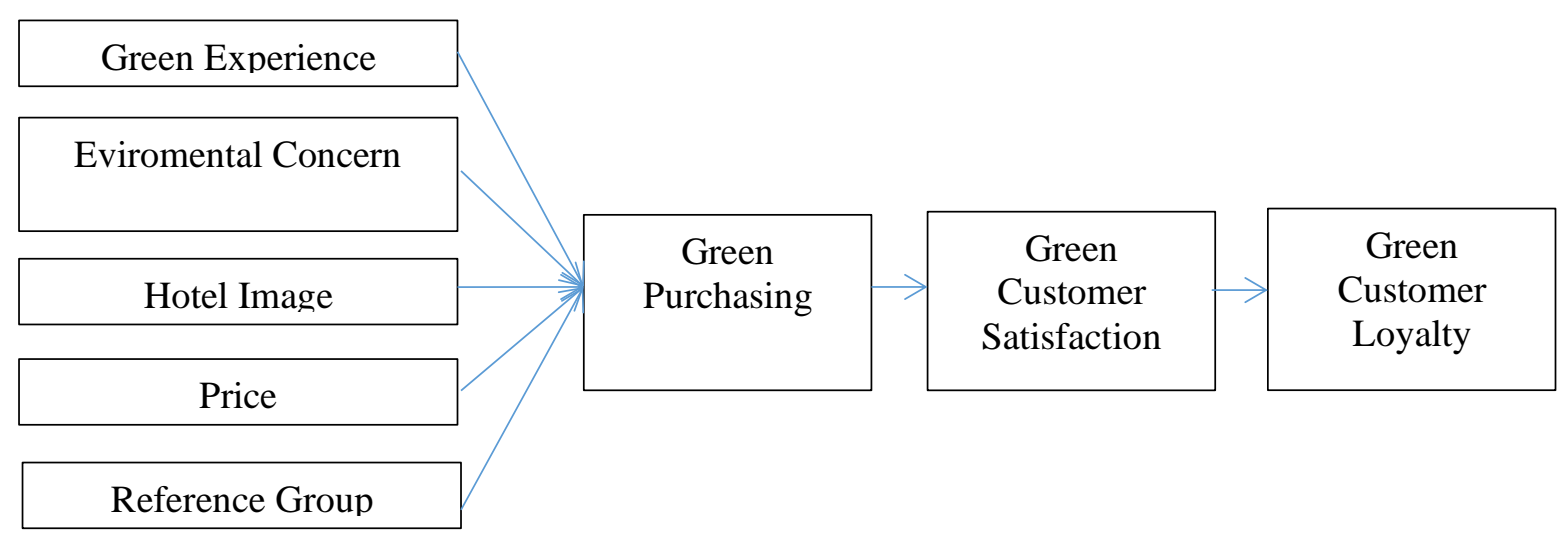

Figure 1. Research Model

Table 1. Operational Variables

\begin{tabular}{|c|c|}
\hline Variables & Indicator (Symbol) \\
\hline $\begin{array}{l}\text { 1. Green } \\
\text { Experience } \\
\text { (EXP) }\end{array}$ & $\begin{array}{l}\text { 1. In my experience green hotel is a hotel do a green practice in general } \\
\text { (EXP1) } \\
\text { 2. Green hotel is a hotel provides information for guest on the property's green } \\
\text { practices (EXP2) } \\
\text { 3. In my experience green hotel is a hotel do advance green practiced by using } \\
\text { energy saving tools (automatic light control, sets indoor cooling } \\
\text { temperature, solars panels, etc.) (EXP3) } \\
\text { 4. In my experience green hotel is a hotel where the site has a green landscape } \\
\text { \& permeable paving (EXP4) } \\
\text { 5. Since I booked this hotel I put green practiced as my consideration (EXP5) }\end{array}$ \\
\hline $\begin{array}{l}\text { 2. Enviroment } \\
\text { al Concern } \\
\text { (EC) }\end{array}$ & $\begin{array}{l}\text { 1. The action that have been taken also seen by others, and justified that I did } \\
\text { green behavior (EC1) } \\
\text { 2. Effort to reduce the amount of energy I use, while others severely abusing } \\
\text { the environment (EC2) } \\
\text { 3. A hotel prioritizing use of local product/biodegradable/eco-friendly product } \\
\text { (EC3) } \\
\text { 4. I am preffer to the companies which practices environmentally friendly } \\
\text { policy (EC4) }\end{array}$ \\
\hline
\end{tabular}




\begin{tabular}{|c|c|}
\hline Variables & Indicator (Symbol) \\
\hline $\begin{array}{l}\text { 3. Hotel } \\
\text { Image } \\
\text { (IMG) }\end{array}$ & $\begin{array}{l}\text { 1. Hotel already well recognized as green hotel (IMG1) } \\
\text { 2. Certification program belongs to the hotel which showing they are green } \\
\text { pratices (IMG2) } \\
\text { 3. Green hotel has luxury image with higher price (IMG3) }\end{array}$ \\
\hline $\begin{array}{ll}\text { 4. } & \text { Harga } \\
\text { (PRICE) }\end{array}$ & $\begin{array}{l}\text { 1. The price charged by green hotels is reasonable (PRICE1) } \\
\text { 2. Green hotel offers good value for money (PRICE2) } \\
\text { 3. Green hotel offers better quality/benefits by support environmentally } \\
\text { friendly pratices (PRICE3) }\end{array}$ \\
\hline $\begin{array}{l}\text { 5. Reference } \\
\text { Group } \\
\text { (REF) }\end{array}$ & $\begin{array}{l}\text { 1. I use green hotel because the influence of the surrounding social } \\
\text { environment (REF1) } \\
\text { 2. I use green hotel because the influence of strong campaign from green } \\
\text { movement (REF2) } \\
\text { 3. I use green hotel because the advice from travel agent (REF3) }\end{array}$ \\
\hline $\begin{array}{l}\text { 6. Green } \\
\text { Purchasing } \\
\text { (GP) }\end{array}$ & $\begin{array}{l}\text { 1. The price of hotel as same as hotel in general (GP1) } \\
\text { 2. Buying by consider may use of them have an impact on environmental } \\
\text { sustainability (GP2) } \\
\text { 3. Prefer choose the product which have low pollution (GP3) }\end{array}$ \\
\hline \multirow[t]{3}{*}{$\begin{array}{l}\text { 7. Green } \\
\text { Customer } \\
\text { Satisfaction } \\
\text { (GCS) }\end{array}$} & $\begin{array}{l}\text { A.Green Attribut (ATT) } \\
\text { 1. The hotel uses environmentally friendly equipment (ATT1) } \\
\text { 2. The atmosphere of hotel (ATT2) } \\
\text { 3. The hotel is very efficient in the use of electricity and water (ATT3) } \\
\text { 4. Invite guests to participate in an energy action program while staying at the } \\
\text { hotel (ATT4) }\end{array}$ \\
\hline & $\begin{array}{l}\text { B. Eco Behaviour of Hotel Staff (STAFF) } \\
\text { 1. Employees always encourages the guests to participate in green program } \\
\text { during stay in the hotel (STAFF1) } \\
\text { 2. Employees are never too busy to respond to our request (STAFF2) } \\
\text { 3. Employees have in-depth knowledge of environmentally friendly programs } \\
\text { (STAFF3) }\end{array}$ \\
\hline & $\begin{array}{l}\text { C. Healthy Food (FOOD) } \\
\text { 1. Hotel providing organic food (FOOD1) } \\
\text { 2. Healthy menu in the majority of food available } \\
\text { (breakfast/dinner/lunch/room's menu) (FOOD2) }\end{array}$ \\
\hline $\begin{array}{l}\text { 8. Green } \\
\text { Customer } \\
\text { Loyalty } \\
\text { (GCL) }\end{array}$ & $\begin{array}{l}\text { 1. It is possible to pay a premium to stay at a hotel that practiced green } \\
\text { programs (GCL1) } \\
\text { 2. Have plans to use the green hotel again when travelling (GCL2) } \\
\text { 3. I will encourage my friends to stay at hotel which practiced green programs } \\
\text { (GCL3) } \\
\text { 4. Have a plan to give testimony to the media (GCL4) } \\
\text { 5. Trying to find information related to similar hotels when travelling (GCL5) }\end{array}$ \\
\hline
\end{tabular}

By adjusting the conditions and characteristics of tourists from Europe, there are at least five antecedent variables that will be tested to see their influence on green purchasing decisions which consisting of 1) green experience as past experience of consumer; 2) the level of guarantee of the reputation of services 4) price, not only on green purchasing, this variable also plays a major role in conventional purchasing decisions, and 5) the influence of reference groups to the decision of purchasing. 
Based on that statement, the related hypotheses proposed as below :

H1: Green experience of consumers in obtaining environmentally friendly services certainly have a major influence to purchase of green hotels. The more experience the greater the opportunity for consumers to use similar products

$\mathrm{H} 2$ : The level of consumer concern of environmental issues has an influence in its decision to purchase green hotel. The higher consumer concern of environmental issues, the higher the chances of consumers to purchase.

H3 : The brand image attached to the hotel is a guarantee that will influence consumers in their purchasing decisions. The more famous and reputable the higher the opportunity for consumers to buy it.

H4 : Prices have a big influence on consumers in their purchasing decisions. The more attractive the price offered the higher the consumer's interest in buying.

H5 : What is the experience of others often affects someone to buy the same product, as well as for environmentallyfriendly products.
The higher the influence of the reference group, the higher the consumer's interest in using a green hotel.

It is improper if consumers with a number of specific characteristics, such as the green consumer, are ignored without ever knowing how to maintain this segment in the future. The possible intervention is to provide the best service so that consumers will feel satisfied while staying at the green hotel. As stated in the literature review above, the dimension of green customer satisfaction refers to the opinion of Bastic and Gojcic (2012) who use eco component as a measure of guest satisfaction, namely green attribute, energy saving facilities; eco-behavior staff, and bio food. The basic facts that will be examined are how green purchases will affect green customer satisfaction, so the hypothesis to be tested are :

H6 : Green purchasing has an influence on green customer satisfaction as measured by a number of dimensions of satisfaction.

According to Ganiyu, Ikechuwku, and Elizabeth (2012) satisfaction can mediate a loyalty, satisfied consumers tend to be loyal. Consumer loyalty in service and hospitality business is very important, keeping the purchase of environmentally e-ISSN: 2407-392X. p-ISSN: 2541-0857 
friendly products complex decision with many considerations (Joshi and Rahman 2015; Yu, Li, and Jai 2017). The construct of the theory of green customer loyalty for tourists using green hotels is basically research that has never been found. Therefore, modeling of this construct will be very important for hoteliers, especially green hotels in building customer loyalty. For the statement, the last hypothesis to be tested in this research are:

H7 : Customers who are satisfied with hotel services will be more loyal to the hotel. The more satisfied the consumer the higher the loyalty.

\section{RESULTS AND DISCUSSION}

Green consumers are a group of consumers with special characteristics and behaviors that are different from ordinary consumers. This segment has more detailed considerations in decision, although these consumers are easy to feel satisfied and have a high loyalty tendency. In this regard, it is interesting to know the antecedent variables that influence this green consumer group in making specific decisions on choosing a green hotel.

The profile and characteristics of the respondents are reported in Table 2. The majority of respondents came from the Netherlands (36\%) and France (33\%), College Graduate (44\%), Male (54\%), and http://ojs.unud.ac.id/index.php/eot worked as professionals (26\%) the visitors of green hotel quietly have a good consumer profile. They have good education most of them are professionals who may have a better economic level.

Table 2. Profile Respondent (N=215)

\begin{tabular}{lll}
\hline Variable & Frequency & Mean \\
\hline Nationality & & \\
Netherlands & 78 & $36 \%$ \\
France & 71 & $33 \%$ \\
Germany & 33 & $15 \%$ \\
UK & 21 & $10 \%$ \\
Spain & 12 & $6 \%$
\end{tabular}

\section{Education}

$\begin{array}{lll}\text { High School } & 42 & 20 \% \\ \text { College Graduate } & 94 & 44 \% \\ \text { Post Graduate } & 79 & 37 \%\end{array}$

\section{Gender}

$\begin{array}{lll}\text { Male } & 116 & 54 \% \\ \text { Female } & 99 & 46 \%\end{array}$

\section{Occupation}

\begin{tabular}{lll} 
Professional & 55 & $26 \%$ \\
Govt Officer & 6 & $3 \%$ \\
House Wife & 38 & $18 \%$ \\
Entrepreneur & 27 & $13 \%$ \\
Student & 19 & $9 \%$ \\
Executive & 32 & $15 \%$ \\
Retirement & 38 & $18 \%$ \\
\hline
\end{tabular}

Regarding to all the hypotheses testing is carried out by the following procedure:

e-ISSN: 2407-392X. p-ISSN: 2541-0857 


\section{Outer Model Testing}

In the phase of measurement model including testing Convergent Validity, Discriminant Validity and Composite Reliability. The results of PLS analysis can be used to test the research hypothesis if all indicators meet the requirements of convergent validity, discriminant validity and composite reliability. Testing at this stage results that all indicators are has convergent validity higher than 0.7 and the average variance extracted (AVE) higher than 0.5. Based on the measurement results and based on the criteria above, the construct is declared reliable.

Table 3. Validity and Reliability Tests

\begin{tabular}{llcc}
\hline Variables & AVE & Composite Reliability & Cronbachs Alpha \\
\hline ATT & 0.900 & 0.973 & 0.963 \\
EC & 0.862 & 0.962 & 0.947 \\
EXP & 0.661 & 0.907 & 0.873 \\
FOOD & 0.902 & 0.949 & 0.892 \\
GCL & 0.819 & 0.958 & 0.945 \\
GCS & 0.674 & 0.949 & 0.939 \\
GP & 0.865 & 0.951 & 0.922 \\
IMG & 0.881 & 0.957 & 0.932 \\
PRICE & 0.792 & 0.919 & 0.876 \\
REF & 0.803 & 0.924 & 0.876 \\
STAFF & 0.905 & 0.966 & 0.948 \\
\hline
\end{tabular}

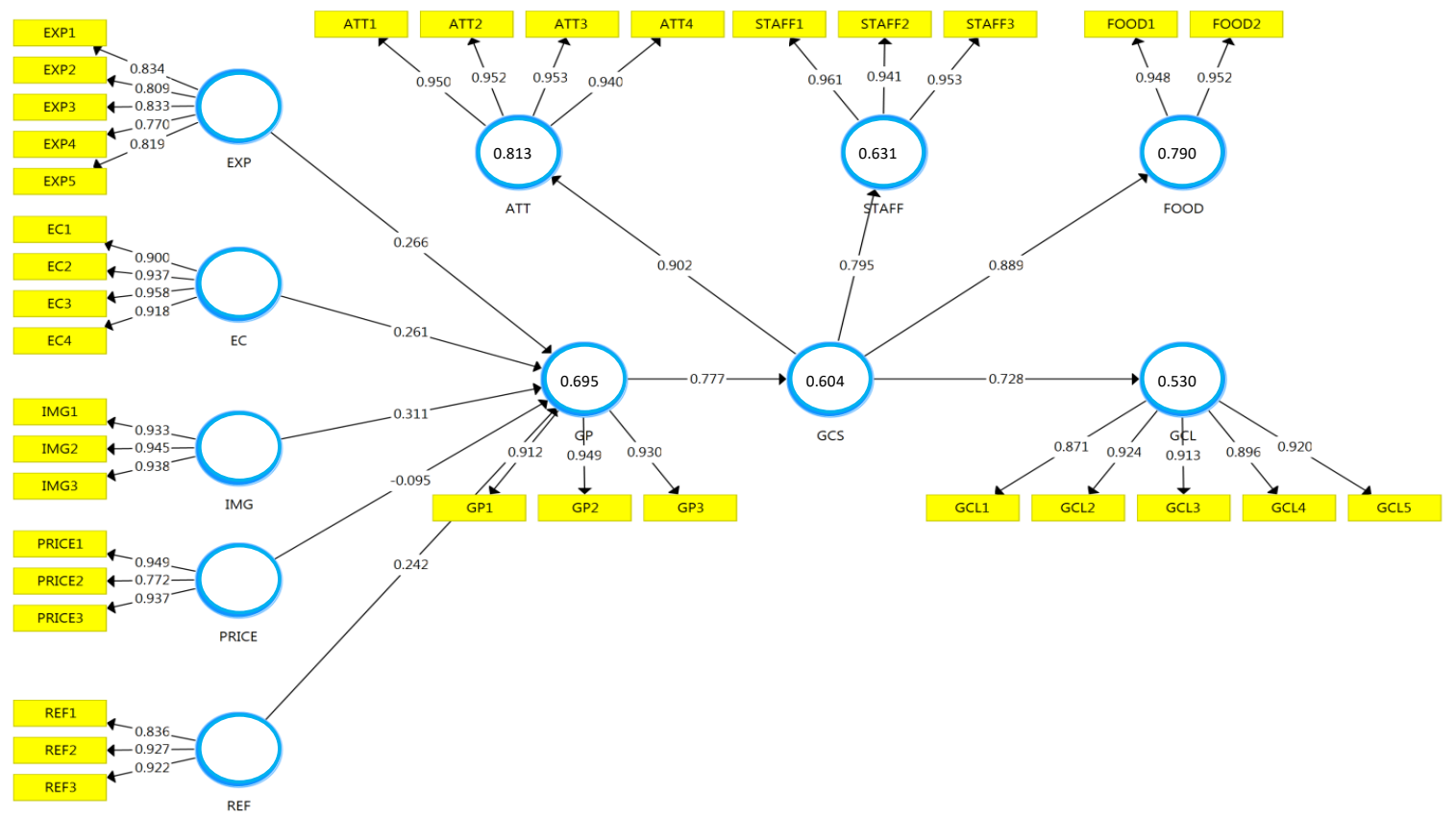

Figure 2. Path Coeffiecient and Loading Factor 


\section{Inner Model Testing}

Testing of the goodness of fit model is based on the $\mathrm{R}$ square value, $\mathrm{Q}$ square predictive relevance and fit of the PLS model as reported at Table 4. Based on the test results it was found that the value of $\mathrm{R}$ square variable has moderate - high predictive accuracy value. The closer to 1 the better the prediction model of the research. The range of $\mathrm{R}$ square is between 0 and 1 , the higher level, the higher predictive accuracy. According to (Henseler and Chin 2010) R square has a value of 0.67 indicating high predictive accuracy, a range of $0.33-0.67$ indicates a low effect, while the $\mathrm{R}$ square value below 0.19 is considered unacceptable. The exogenous variables can explain the endogenous dependent variable.
In the assessment based on the $\mathrm{Q}$ square the rule is if value of greater than zero for a particular reflective endogenous latent variable indicate the path model's predictive relevance for a specific dependent construct (Hair et al. 2014). Prediction relevance test (Q square) also known as the Stone Geisser test term which is performed to determine the predictive capability with a blindfolding procedure if the value obtained is 0.02 (Small), 0.15 (Medium), and 0.35 (Big). Based on the test results, it was found that $\mathrm{Q}$ Square for all constructs was above 0.35 or Big. This means that the construct is very good with high predictive relevance. The overall test results of the PLS goodness of fit model indicate that the PLS model has fulfilled the goodness of fit and allows it to be used to test the research hypothesis.

Table 4. Goodness of Fit Model Testing Result

\begin{tabular}{llll}
\hline Variables & Parameter of Goodness of Fit & & \\
& R Square & Q Square & \\
& $\left(\mathrm{R}^{2}=0.19-0.33\right)=$ Weak & $(>0)$ or & $<0.10$ \\
& $\left(\mathrm{R}^{2}=0.33-0.67\right)=$ Moderate & $\left(\mathrm{Q}^{2}=0.02\right)=$ Small & \\
& $\left(\mathrm{R}^{2}>0.67\right)=$ Strong & $\begin{array}{l}\left(\mathrm{Q}^{2}=0.15\right)=\text { Sedang } \\
\left(\mathrm{Q}^{2}=0.35\right)=\text { Besar }\end{array}$ & \\
\hline ATT & 0.813 & 0.686 \\
\hline FOOD & 0.790 & 0.681 & \\
\hline GCL & 0.530 & 0.405 & \\
\hline GCS & 0.604 & 0.373 & \\
\hline GP & 0.695 & 0.558 & \\
\hline STAFF & 0.631 & 0.538 & \\
\hline
\end{tabular}


In the testing of hypothesis as reported at Table 5, it can be seen that European visitors in their decision to choose green hotels tend to consider the Green Experience, Environmental Concern, and Hotel Image, and Reference Group, but tend to be ignored The Price. In Indonesia tourists from Europe are seen as sophisticated travelers both in terms of taste and style. They are considered to have an adequate level of education and high awareness of the environment, care for local wisdom, and have high spending abilities. So that in this context it is natural that price factors are not the main factor in purchasing decisions. The decision to have a green hotel is higher, possibly more inclined to factors of experience, high awareness of the environment, image and the influence of people who ever stayed before, or other groups

Table 5. Hypotheses Testing Result

\begin{tabular}{|c|c|c|c|c|c|}
\hline & Research Hypotheses & & C.R & $\mathbf{P}$ & Conclusion \\
\hline H1: & Enviromental Concern & $\rightarrow$ Green purchasing & 2.615 & 0.000 & Accepted \\
\hline $\mathrm{H} 2$ : & Green Experience & $\rightarrow$ Green purchasing & 2.926 & 0.000 & Accepted \\
\hline H3: & Hotel Image & $\rightarrow$ Green purchasing & 3.007 & 0.003 & Accepted \\
\hline H4: & Hotel Price & $\rightarrow$ Green purchasing & 1.019 & 0.309 & Rejected \\
\hline H5: & Reference Group & $\rightarrow$ Green purchasing & 3.221 & 0.000 & Accepted \\
\hline H6: & Green Purchasing & $\rightarrow$ Green Customer Satisfaction & 15.239 & 0.000 & Accepted \\
\hline H7: & Green Customer Satisfaction & $\rightarrow$ Green Customer Loyalty & 14.846 & 0.000 & Accepted \\
\hline
\end{tabular}

Sig. $5 \%$

Based on the results of testing in $\mathrm{H} 6$ showed that green consumers who bought green hotels were also satisfied with a number of eco-friendly services provided by the hotel i.e attributes, staff, and food. This can be interpreted that green consumer is basically a hassle-free segment, easy to managed, and less complained. Green purchasing has a significant effect on green customer satisfaction. In testing the effect of green customer satisfaction on green customer loyalty it also found a significant http://ojs.unud.ac.id/index.php/eot effect. This means that satisfied consumers tend to be loyal.

As a preliminary research, the construct model in this study is quite reliable in order to see the tendency of European visitors behaviour in using green hotels. Based on the results numbers of hypotheses testing, green customer loyalty can be formed from the determinants that influence consumers' decision to buy green hotels. If the influential determinants can be well accommodated (Green Experience, e-ISSN: 2407-392X. p-ISSN: 2541-0857 
Environmental Concern, Hotel Image, and Reference Group) so green customer satisfaction able to be a good mediator between the purchasing and loyalty.

That results of this study agree with the statement that consumer loyalty is closely related to customer satisfaction (Kheng et al. 2010; Ganiyu, Ikechuwku, and Elizabeth 2012; Mohsan et al. 2011; Saleem and Raja 2014; Ganiyu 2017). Satisfied consumers have a tendency to be loyal (Orie Berezan et al. 2013). Loyalty itself can be formed from the initial stage of the first consumer to purchase a product (Ganiyu 2017). The main reason European visitors choosing green hotel is solely of awareness of green behavior instead of price. Those who have a high awareness about environment will easily accept any form of green service. In other words, a sense of responsibility towards the environment also makes consumers tend to be loyal to what they have chosen. A number of studies have claimed that green hotels are expensive and uncomfortable hotels due to the efficiency issues (Johri and Sahasakmontri 2016; Yu, Li, and Jai 2017; Chan and Chan 2013) but there are many consumers who willing to pay more with slightly reduce the feeling of comfort (Dimara, Manganari, and Skuras 2015; Kusliwal and Agarwal 2015). These happen also to European visitors who choosed green hotel.
Price is not really an important reason for European visitors. However, a number of studies have claimed that prices are an important factor in green product purchasing decisions (Anvar and Venter 2014; Joshi and Rahman 2015) but this does not occur in the case of green hotel purchasing decisions. Satisfied consumers will be a loyal consumer. Green customer satisfaction has a strong and significant effect on green customer loyalty.

\section{CONCLUSION}

Green Purchasing, which is defined as the purchase of green hotels by European visitors, is significantly influenced by the determinants of Green Experience, Environmental Concern, Image, and Reference Group. Green purchasing has a significant effect on Green Customer Satisfaction, which means that green consumers are also satisfied with the ecofriendly services (attributes, staff, and food) provided by the hotel. Consumers who are satisfied tend to be loyal, they most likely to use similar product in the future. This pretty statement explains that European visitors has the characteristics of being loyal consumer. Overall, it can be concluded that the research model of green consumer which turns out to be loyal customers can be accepted.

\footnotetext{
e-ISSN: 2407-392X. p-ISSN: 2541-0857
} 
This research is expected to contribute to hotelier in order to build green customer loyalty. Creating loyalty to consumers who have high awareness about the environment is easier than consumers in general. Green consumers are not sensitive to prices as long they judge the product is well. It is important to increase awareness of environmentally friendly behavior. Attributes of hotel, staff performance, and food are among the services that can provide satisfaction to visitors.

\section{REFERENCES}

Anvar, Muntaha, and Marike Venter. 2014. "Attitudes and Purchases Behaviour pf Green Product Among Generation Y Consumer in South Africa." Mediterranean Journal of Social Sciences 5 (21). doi: 10.5901/mjss.2014.v5n21p183.

Bastic, Majda, and Slavka Gojcic. 2012. "Measurement Scale for EcoComponent of Hotel Service." Intenational Journal of Hospitality Management 31 (3):1012-20. doi: http://dx.doi.org10.1016/j.ijhm.2011. 12.007.

Berezan, Orie, Michelle Millar, and Carola Raab. 2014. "Sustainable Hotel Practices and Guest Satisfaction Levels." International Journal of Hospitality \& Tourism Administration 15:1-18. doi: http://dx.doi.org/10.1080/15256480. 2014.872884.
Chan, Xing, and K Chan. 2013. "Perception of Green Hotels Among Tourist in Hong Kong : An Exploratory Research,." Service Marketing Quarterly 34:339-52. doi: https://doi.org/10.1080/15332969.20 13.827069 .

Chang, Nai-Jen, and Cher Min Fong. 2010. "Green Quality, Green Corporate Image, Green Customer Satisfaction, and Green Customer Loyalt." African Journal of Business Management 4 (13):2836-44.

Dimara, Efthailia, Emmanouda Manganari, and Dimitri Skuras. 2015. Willingness to pay premium for Green Hotels, Fact or fad ?,. Paper presented at the International Marketing Trends Conference, Greek.

Ganiyu, R.A. 2017. "Customer Satisfaction and Loyalty: A study of Interrelationships and Effects in Nigerian Domestic Airline Industry." Oradea Journal of Business and Economics 2 (1).

Ganiyu, Rahim Ajao, Igantiius Ikechuwku, and Adeoti Olusola Elizabeth. 2012. "Is Customer Satisfaction an Indicator of Customer Loyalty? ." Australian Journal of Business and Management Research 2 (7):14-20.

Hair, Josep F., Thomat M. Hult, Christian M. Ringle, and Marco Sarstedt. 2017. A Primer on Partial Least Square Structrual Equation Modeling (PLS$S E M)$ 2ed: Sage Publication Inc.

Hair, Joseph F., William C Black, Beery J Babin, and Rolp E Anderson. 2014. Multivariate Data Analysis. USA: Pearson New International. 
Henseler, J., and W.W. Chin. 2010. "A comparison of approaches for the analysis of interaction effects between latent variables using partial least squares path modeling " Structural Equation Modeling: A Multidisciplinary Journal 17 (1):82109.

Johri, Lalit M., and Kanokthip Sahasakmontri. 2016. "Green marketing of cosmetics and toiletries in Thailand." Journal of Consumer Marketing 15 (3):265-81. doi: http://dx.doi.org/10.1108/073637698 10219134.

Joshi, Yatish, and Zillur Rahman. 2015. "Factors Affecting Green Purchase Behaviour and Future Research Directions " International Strategic Management Review 3:128-43. doi: http://dx.doi.org/10.1016/j.ism.2015. 04.001 .

Kheng, Lo Liang, Osman Mahamad, Ramayah, and Rahim Mosahab. 2010. "The Impact of Service Quality on Customer Loyalty: A Study of Banks in Penang, Malaysia International Journal of Marketing Studies 2 (2).

Kusliwal, Noeti, and Srishli Agarwal. 2015. "An Exploratory Study on Women's Perception and Choice of Preference towards the Green Attributes of Hotel Industry." International Journal of Engineering Technologu, Management and Applied Science 3 (Special Issues).

Mohsan, Faizan, Muhammad Musarrat Nawaz, Sarfraz Khan, Zeeshan Shaukat, and Numan Aslam. 2011. "Impact of Customer Satisfaction on Customer Loyalty and Intentions to Switch: Evidence from Banking Sector of Pakistan " International Journal of Business and Social Science 2 (16).
Mun, Tang Sook. 2014. "Factors That Influence Green Purchase Behaviour of Malaysian Consumers " In. Malaysia: Universiti Tunku Abdul Rahman Faculty of Accountancy and Management

Orie Berezan, Carola Raab, Michelle Yoo, and Curtis Love. 2013. "Sustainable hotel practices and nationality: The impact on guest satisfaction and Guest Intention to Return " International Journal of Hospitality Management 34:227- 33. doi: http://dx.doi.org/10.1016/j.ijhm.2013 .03.010.

Saleem, Hamad, and Naintara Sarfraz Raja. 2014. "The Impact of Service Quality on Customer Satisfaction, Customer Loyalty and Brand Image: Evidence from Hotel Industry of Pakistan." Middle-East Journal of Scientific Research 19 (5):706-11. doi: https://doi.org/10.9790/487X1616117122.

Theotokis, Ariestieidis, and Emanouela Manganari. 2015. "The Impact of Choice Architecture on Sustainable Behaviour : The Role of Guil." Business Ethic (2016) 136-575-585.

$\mathrm{Yu}$, Yixiu, $\mathrm{Xu} \mathrm{Li}$, and Tun-Min (Catherine) Jai. 2017. "The Impact of Green Experience on Customer Satisfaction : Evidence from TripAdvisor." International Journal of Contemporary Hospitality Management 29 (5):1340-61. doi: https://doi.org/10.1108/IJCHM-072015-0371.

Yuniati, Nining, Sony Heru Priyanto, Lieli Suharti, and Linda Kusuma. 2020. "Loyalty of Green Tourist : Mediating Role of Satisfaction." $E$ Journal of Tourism 7 (1):114-25. doi: https://doi.org/10.24922/eot.v7i1.549 51

e-ISSN: 2407-392X. p-ISSN: 2541-0857 